\title{
Techniques for sperm evaluation using fluorescent probes
}

\section{Técnicas para avaliação espermática utilizando sondas fluorescentes}

\author{
Andrielle Thainar Mendes Cunha ${ }^{1}$; José Oliveira Carvalho²; \\ Margot Alves Nunes Dode ${ }^{3 *}$
}

\begin{abstract}
A variety of laboratory tests were developed to obtain more reliable results of sperm evaluation and increase the accuracy of sperm fertility predictions. These tests detected damage of sperm specific compartments or organelles, which cannot be detected in routine sperm analysis. The use of fluorescent probes and detection using fluorescent microscopy or flow cytometry is an important tool but a more precise and accurate laboratory test is needed. Propidium iodide and 6-carboxyfluorescein diacetate are used for evaluations of plasmatic membrane integrity. Fluorescein isothiocyanate, associated with conjugated lecithin Psium sativum or Arachis hypogaea, are used for evaluations of acrosome integrity. Two probes, MitoTracker or Rhodamine123, are generally used to measure the absence or presence of mitochondrial potential. However, a better option is 5,5'; 6,6' - tetrachloro - 1,1'; 3,3' tetraetilbenzimidazolil-carbocyanine (JC-1) dye, which assesses not only the presence of mitochondrial potential and distinguished spermatozoa with poorly and highly functional mitochondria. Two techniques, TUNEL or COMETA, and the Acridine Orange Test (AOT) dye are used to evaluate chromatin integrity. A fluorescence technique based on chlortetracycline (CTC) or Merocyanine 540 is used to estimate whether sperm pass by or through the capacitation process. This review focuses on the fluorescent probes that are most widely used to evaluate plasma membrane integrity, capacitation, acrosome integrity, chromatin integrity and mitochondrial potential.
\end{abstract}

Key words: Fluorescence microscopy, sperm, cryopreservation

\section{Resumo}

Diversos testes laboratoriais têm sido desenvolvidos com o intuito de obter resultados confiáveis nas avaliações espermáticas, aumentando a qualidade e a confiabilidade do sêmen utilizado em técnicas de reprodução assistida. Esses testes têm permitido detectar danos em compartimentos e organelas específicas da célula espermática, que não são detectados nas análises de rotina. Dentre esses testes, o uso de sondas fluorescentes e sua deteç̧ão em microscópio de epifluorescência ou citometria de fluxo se tornaram ferramenta importante quando uma avaliação mais acurada é necessária. Para a avaliação da integridade de membrana plasmática, pode ser utilizado o iodeto de propídio, associado ao diacetato de 6-carboxifluoresceína. As avaliações de integridade acrossomal podem ser feitas através do isotiocianato de fluoresceína, associado às lecitinas conjugadas, como a Psium sativum ou Arachis hypogaea. O potencial mitocondrial pode ser avaliado quanto à ausência ou presença através da sonda Mitotracker ou Rodamina 123. Outra opção ainda melhor pode ser observada utilizando o corante iodeto de 5,5'; 6,6' - tetracloro - 1,1'; 3,3' - tetraetilbenzimidazolil-carbocianina (JC-1), este corante avalia a presença do potencial mitocondrial e avalia quanto à classificação do grau. Para avaliar a integridade

\footnotetext{
${ }^{1}$ Discente, Universidade de Brasília, UnB, Brasília, DF, Brasil. E-mail: andriellethaina@hotmail.com

2 Discente, Universidade de São Paulo, USP, Piracicaba, SP, Brasil. E-mail: joseocneto@hotmail.com

${ }_{3}^{3}$ Pesquisadora, Empresa Brasileira de Pesquisa Agropecuária, Embrapa Recursos Genéticos e Biotecnologia, Brasília, DF, Brasil. E-mail: margot.dode@embrapa.br

* Author for correspondence
} 
de cromatina, pode ser empregado o uso de duas técnicas conhecidas como TUNEL ou COMETA, ou pode ser utilizado o corante Acridine Orange Test (AOT). Para avaliar se o espermatozoide está passando ou passou pelo processo de capacitação, pode ser utilizada a técnica de fluorescência a base de clortetraciclina, o CTC, quelante do cálcio, ou a Merocianina 540. Esta revisão enfatiza as principais sondas fluorescentes disponíveis para avaliar a integridade de membrana plasmática, capacitação, integridade acrossomal, integridade da cromatina, e potencial mitocondrial.

Palavras-chave: Microscopia de fluorescência, espermatozoide, criopreservação

\section{Introduction}

Spermatozoa evaluation is used to predict the fertility potential of a sire, identify sires with higher fertility and establish reliable characteristics for use as fertility indicators (AMANN; HAMMERSTEDT, 1993; DE-PAUW et al., 2002; BANASZEWSKA et al., 2015).

Assessments of semen quality conventionally rely on microscopic evaluations of sperm parameters including subjective analyses of motility, percentage of normal sperm morphology and sperm concentration. However, the prediction of male fertility cannot be truthfully based on these parameters because evaluations of other physiological characteristics that are critical elements for fertilization, such as capacitation and acrosome reaction, are also necessary. Sperm samples that exhibit normal motility and morphology do not always achieve acceptable rates of fertilization because the sperm may have structural or functional abnormalities that may impair sperm and egg interactions, or embryo development.

Therefore, many researchers investigated the development of laboratory tests that evaluate sperm cells with greater accuracy, higher objectivity and repeatability (CELEGHINI et al., 2007; CARVALHO et al., 2010; HOSSAIN et al., 2011; STANDERHOLEN et al., 2014; SAPANIDOU et al., 2015). No single evaluation technique is sufficiently sensitive to determine fertility, but combinations of various parameters more accurately estimate the fertilization potential of a sperm sample (RODRIGUEZ-MARTINEZ, 2006; PEÑA, 2015).
Fluorescent dyes are widely used to evaluate the functionality of several sperm compartments.

This review evaluates some fluorescent probes techniques to assess sperm cells characteristics and gathers evidence from the literature on the benefits of the use of these tools to improve predictions of the fertilization capacity of these cells.

\section{Fluorescence microscopy}

Fluorescence is the emission of light by a molecule that has absorbed light or other electromagnet radiation within nanoseconds. The emitted light has a longer wavelength and lower energy than the absorbed light in most cases. The difference between the energy of excitation and emission wavelengths is a unique property for each particular fluorochrome, which is a critical factor for the sensitivity of fluorescence techniques. Light or magnetic radiation in a restricted wavelength causes excitation when it reaches a particular molecule in a ground state. The excited molecule enters an intermediate transition that leads to a relaxed state followed by a return to the ground state and emits visible light (fluorescence) (PLOEM; WALTER, 2001).

Fluorophores are classified primarily by light absorption capacity, and each color generates an emission of a specific color, The emission of light varies between 405-800 nm ultraviolet and 800-1200 nm infrared (PLOEM; WALTER, 2001; LICHTMAN; CONCHELLO, 2005), and different optical filters in the microscope select the wavelength range based on the dye.

Fluorescence microscopy, flow cytometry and 
fluorescence-activated cell sorting are the most widely used complex fluorescence technologies. Fluorescence microscopy allows the study of protein location and evaluations of cell organelles or compartments, that are involved in ion transport and cellular metabolism (COMBS, 2010).

Fluorescence microscopy and confocal microscopy are used to assess various sperm characteristics such as the membrane, acrosome and chromatin. One advantage of fluorescence microscopy is the ability to identify fluorescent signals in individual cells (PETRUNKINA; HARRISON, 2013).

The confocal microscope uses a laser as a light source and offers some advantages compared to traditional microscopy, including the ability to control the depth of the field, background removal or reduction of the focal plane and the possibility of obtaining serial optical sections in thick samples.

A flow cytometer has light sources and filter units that function similarly to a fluorescence microscope. It also has a flow chamber with photomultipliers that allow for more sensitive detection and a unit that processes the collected data. The cell suspension is injected into the chamber and each event (cell) passes through light beams that are perpendicular to the flow. The passage of cells is focused through a hydrodynamic system, and the material being measured remains suspended in a saline solution. This system can detect up to 10.000 events per second (HOSSAIN et al., 2011; PEÑA, 2015).

Flow cytometers are the result of the development of a variety of tools and the application of techniques that were developed in computing, biotechnology (production of monoclonal and fluorochrome antibodies), and laser beam and electronic technologies. These tools enable evaluations of the physical, chemical and biological characteristics of various cells and microorganisms. Flow cytometry has become a widely used technique for multiparametric analyses of cell populations because of its unique ability to analyze multiple parameters simultaneously on a single cell in a rapid, practical and accurate manner.

Cytometers are classified as bench-top analyzers and cell sorting flow cytometers (HOSSAIN et al., 2011) in the sexing of sperm. Modern equipment includes flow cytometers that have an attached computer and specific software that produces specific images, which are known as flow cytometry image or FCS image.

\section{Fluorophores}

Fluorophores are the components of a molecule that cause fluorescence. A fluorophore is the functional group of a molecule that absorbs energy from a specific wavelength and subsequently reemits light at a longer wavelength (i.e., less energy). Fluorophores are also known as fluorochrome dyes or fluorescent probes. Biological samples are exposed to fluorophores and taken to a microscope. Ultraviolet light radiation excites the flurophores in the sample, which causes the fluorophores to emit visible light (LICHTMAN; CONCHELLO, 2005; COMBS, 2010).

Molecules with fluorescent properties absorb energy through the wavelengths emitted by the light. The energy absorbed by the molecule causes the electrons to move in different orbits, and all of the energy in the photon is transferred to the fluorophore when the electrons return to the low power state, which results in fluorescence emission (LICHTMAN; CONCHELLO, 2005).

Many fluorophores are commercially available, such as ethidium bromide (EB), propidium iodide (PI), 6-carboxyfluorescein diacetate (C-FDA), Hoechst 33258, Hoechst 33342, SYBR-14, annexin V/PI, YoPro-1, Merocyanine 540 and ethidium homodimer, which are commonly used for plasma membrane (PM) evaluations. The acrosome can be evaluated using acidophilic probes, such as Lysotracker Green DND-26 (LYSO-G) (CELEGHINI et al., 2007) or isothiocyanate 
fluorophore (FITC) associated with agglutinin as Pisum sativum (PSA), Ricinus communis agglutinin (RCA), agglutinin of Arachis hypogea (PNA) or Concanavalia ensiformis (Con-A) (CELEGHINI et al., 2007; CARVALHO et al., 2010; KUMAR et al., 2014; SOSA et al., 2015).

TUNEL and COMETA tests are used for chromatin evaluations (HELLMAN et al., 1994), and the sperm chromatin structure assay (SCSA) uses Acridine Orange (AO) dye (YÁNIZ et al., 2013). Chromomicina A3 dye (CMA3) (HOSSAIN et al., 2011) can also be used to examine chromatin structure. The monitoring of mitochondrial activity may be performed using Rhodamine 123 , iodide 5,5 ', 6,6'-tetrachloro 1,1,3,3'tetraetilbenzimidazolilcarbocianina (JC-1) (REEN et al., 1991; THOMAS etal., 1997; KUMAR et al., 2014) or MitoTracker Green, Red and Orange fluorophores (SILVA; GADELLA, 2006; FARAH et al., 2013).

\section{PM Integrity}

The PM plays a key role in the survival of sperm in the female reproductive tract and the maintenance of their fertilizing ability by acting as a selective barrier between components of the intracellular and extracellular environment (GWATHMEY et al., 2006).

An intact and functionally active PM is required for sperm metabolism, capacitation, acrosome reaction and oocyte binding and penetration (BRITO et al., 2003). Therefore, membrane functionality is an important parameter to assess the fertilizing capacity of sperm. Mocé and Graham (2008) demonstrated that PM integrity was synonymous to sperm viability.

Many studies were based on the idea that an intact PM prevents certain dyes from entering the sperm cell. These studies were initially performed using supravital dyes, such as eosin in combination or not with nigrosine (HANCOCK, 1951) and later with trypan blue (WILSON et al., 1969), which is a negatively charged dye that does not enter into cell with an intact PM.

Initial studies of PM integrity using fluorescent probes in spermatozoa, used ethidium bromide (BILGILI; RENDEN, 1984; HALANGK et al., 1984), which exhibits DNA specificity and only penetrates cells with damaged PM. EB fluorescence increases when it intercalates into the double helix (PAL et al., 1998). However, the use of this fluorochrome is restricted because of its high toxicity.

Other fluorescent probes for DNA were tested because of the restricted use of EB. These probes are grouped into two categories. One group is membrane-impermeable dyes, which pass through damaged membranes and are directly observable under the microscope, such as Hoechst 33258, YoPro-1 and IP (CELEGHINI et al., 2007; HOSSAIN et al., 2011), 4,6-diamino-2-phenyl indole (DAPI) and Acridine Orange (AO) (FARAH et al., 2013). The other group are permeable dyes, which cross the intact cell membrane and are held in viable spermatozoa, such as SYBR-14, and Hoechst 33342. C-FDA is another widely used probe for evaluations of PM. C-FDA is permeable to the intact membranes in its normal fluorescent form. C-FDA undergoes an enzymatic reaction inside the cell, and is hydrolyzed by an esterase to release free 6-Carboxyfluorescein. This freed probe is highly fluorescent and impermeable to intact membranes. Therefore, it is retained within the cells and fluoresces green (GARNER et al., 1986).

Probes with DNA affinity, such as SYBR-14, are more stable than probes that are subject to enzymatic reactions, such as C-FDA. Therefore, the former probes are preferred for the staining of sperm DNA.

Carvalho et al. (2010) compared the results of membrane integrity evaluated using fluorescence microscopy using C-FDA associated with IP to bright field microscopy using supravital dye and demonstrated that the proportion of sperm with an 
intact membrane was lower when evaluated using fluorescence microscopy. Brito et al. (2003) found similar results, which suggests greater reliability when fluorescence microscopy is used.

\section{Capacitation}

The capacitation process is the physiological changes that sperm must undergoes in the reproductive tract of the female to become capable of fertilizing an oocyte (BARTH; OKO, 1989). This process refers to the removal or changes in molecules that stabilize sperm PM. the cellular components that are involved in the capacitation process include albumin, sodium bicarbonate and calcium $(\mathrm{Ca} 2+)$ (HARRISON et al., 1992). Changes in the intracellular metabolism of sperm (PEREZ et al., 1996; BERGQVIST et al., 2007) due to events such as cholesterol efflux, changes in PM permeability and increased in $\mathrm{Ca}+$ ions influx (FLESCH; GADELLA, 2000) are more difficult to assess.

Therefore, themostwidely used probes to evaluate capacitating cells are lipophilic Merocyanine 540 and hydrochloride chlortetracycline (CTC).

Merocyanine 540 acts as a marker for the degree of lipid disorder of the PM, which indicates membrane destabilization (initial change of capacitation), and increases the fluorescence emission intensity (FERNANDEZ-SANTOS et al., 2007; CABALLERO et al., 2009).

CTC in which fluorescence is activated by bounding to free calcium ions, was proposed as a method to evaluate of sperm capacitation. CTC was initially tested in mice (SALING; STOREY, 1979) and later in other species. CTC fluorescence distribution changes in the PM of the sperm head during capacitation due to the uptake of $\mathrm{Ca}$ (final stage of capacitation) (SALING; STOREY, 1979). $\mathrm{CTC}$ is a $\mathrm{Ca}^{2+}$ chelator, and it indicates the location of $\mathrm{Ca}^{2+}$ in the PM (FRASER et al., 1995). This characteristic suggest that the CTC technique is advantageous compared to other techniques because it allows a differentiation between cells with intact and reacted acrosomes and also classified cells with intact acrosomes into different categories.

Three fluorescence patterns were defined for CTC staining: Standard F, from Full, due to the presence of full fluorescence in the sperm head, which indicates non-capacitated sperm with intact acrosome; standard B, from Banded, due to the brilliant distribution of fluorescence in the acrosome and lack of brightness in the post-acrosome region, which indicates capacitated sperm with an intact acrosome; and standard AR, from acrosome reaction, which corresponds to the absence of a fluorescent glow in the head and indicates spermatozoa with a reacted acrosome (FRASER et al., 1995; CORMIER et al., 1997).

Several studies were performed to correlate capacitation evaluations and fertility. Collin et al. (2000) and Gillan et al. (2008) did not identify a correlation between the staining patterns of CTC and fertility rate. In contrast, Thundathil et al. (1999) found that the proportion of non-capacitated cells correlated to bull fertility.

Capacitation involves several interdependent events. Therefore, the ideal test would evaluate all capacitation stages simultaneously to avoid erroneous estimations of sperm functionality.

\section{Acrosome integrity}

The acrosome is located in front of the sperm head, and it is formed by two membranes that contain inside glycoproteins, sugars and enzymes, such as hyaluronidase and acrosin (FLESCH; GADELLA, 2000; GILBERT, 2003). These enzymes help in the fertilization process by participating in the digestion of the zona pellucida and allowing the entry of the genetic material of the sperm into the oocyte (BARTH; OKO, 1989; KNOBIL; NEILL, 2006). Therefore, acrosome integrity is key for successful fertilization (ZHANG et al., 1990). 
Numerous probes are used to evaluate acrosome status and PM integrity. The acid content of the intact acrosome vesicle, allows the use of acidophilic probes such as Lysotracker Green DND-26 (LYSO-G) or anti-acrosin (THOMAS et al., 1997), and anti-hyaluronidase antibodies (BACCETTI et al., 1999). Acrosome integrity may also be measured using conjugated lectins because of its glycoprotein environment. Conjugated lectins bind to glucose, mannose, galactose, $\mathrm{N}$-acetylglucosamine and other carbohydrate-specific glycoproteins that are exclusively located in the acrosome.

The most commonly used lectins are PSA or PNA, depending on the mammal species (SILVA; GADELLA, 2006; MACHADO et al., 2009; CARVALHO et al., 2010; CARRETERO et al., 2015). Triticum vulgare (WGA) (BAKER et al., 2004; SILVA; GADELLA, 2006) and Con-A (SILVA; GADELLA, 2006) are also used.

These agglutinins should be conjugated to fluoresceins, such as FITC (BAKER et al., 2004) or R-phycoerythrin (RPE), for microscopy visualization (GADELLA; HARRISON, 2000). Lectins are impermeable to intact acrosomes, but reacted or damaged acrosomes allow the entry of these macromolecules. PNA binds to glycoproteins of the outer acrosome membrane, and PSA identifies binds to matrix enzymatic components of the acrosome lumen by binding specifically to the $\alpha$-mannosidase sugar that is found in the acrosome content (CROSS; MEIZEL, 1989; SILVA; GADELLA, 2006). The presence of a green color region indicates a reacted acrosome in non-fixed cells. A fluorescent acrosome is considered intact in sperm fixed and permeabilized sperm (SILVA; GADELLA, 2006).

Acrosome evaluation may exhibit different results in the same sample when different techniques are used. Carvalho et al. (2010) identified a higher percentage of live sperm with intact acrosomes by using TB dye associated with giemsa compared to PNA staining. Valcárcel et al. (1997) examined three types of conjugated lectins (PNA, PSA and WGA), and found no difference in the results, which indicates that techniques using different lectins may produce similar results. Mocé and Graham (2008) identified a correlation between the number of live sperm with intact acrosomes and sperm motility, whether sperm were assessed subjectively or using CASA (Computer Assisted Sperm Analyses).

Chan et al. (1996) found a positive correlation between the percentage of sperm with intact acrosome and fertilization rates of zona-free hamster oocytes. In contrast, Gillan et al. (2008) found no correlation between the percentage of cells with intact acrosome and fertility. Similar results were observed by Mocé et al. (2006), but an increase in the correlation with fertility was noted when they grouped with other characteristics.

\section{Chromatin integrity}

The evaluation of chromatin damage is an important aspect of sperm analysis because some sperm with chromatin abnormalities can fertilize the oocyte, but the embryo development is impaired, which leads to a high rate of embryonic death (ELLINGTON et al., 1998; KHALIFA et al., 2008; KATO; NAGAO, 2015).

Changes in chromatin may occur due to various factors, including, toxic and pathogenic agents, gene mutations, chromosomal abnormalities, high levels of oxidative stress and the loss of testicular thermoregulation (KARABINUS et al., 1997). All of these factors can result in DNA damage, such as strand breaks or fragmented DNA.

Sperm DNA fragmentation is assessed using the terminal deoxynucleotidyl transferase mediated dUDP Nick end labeling (TUNEL) test (MARTINS et al., 2007) and the single cell gel electrophoresis (COMETA) test (HELLMAN et al., 1994). The TUNEL test consists of the incorporation of nucleotides labeled with FITC at the free region $\left(3^{\prime} \mathrm{OH}\right)$ of all free breaks in the DNA strands 
(YOUNG et al., 2003). The level of labeling in each sperm is quantified using flow cytometry to indicate the degree of strand breakage within the sperm head. The incorporation of fluorochromeconjugated deoxyribonucleotide on the free breaks regions of DNA is amplified using a secondary enzymatic reaction. The labeling of sperm with green fluorescence indicates the presence of DNA fragmentation, and sperm that exhibit blue fluorescence are negative for fragmentation (MARTINS et al., 2007).

The COMETA test is based on the principle that when sperm DNA breaks, the region where this occurs becomes negatively charged. Therefore, exposure of the DNA fragment to an electric field results in the migration of the DNA fragment out of the nucleus and migration to the positive pole. Sperm with DNA damage exhibit a tail similar to comets under fluorescence microscopy when the sperm are stained with EB, DAPI or other dyes. DNA damage is evaluated based on the fluorescence intensity and the length of the tail extension(FARAH et al., 2013).

Another test to evaluate chromatin structure is AO dye. This fluorophore assesses DNA stability to acid or heat denaturation. The fluorochrome intercalates the double-stranded DNA as a full monomer and fluoresces green. The fluorochrome binds to the single-stranded DNA in the form of aggregates and emits a red/orange fluorescence if the DNA is damaged (KOSOWER et al., 1992; AGARWAL; SAID, 2003). Therefore, sperm with normal DNA emit green fluorescence, and sperm with abnormal DNA, emit a color ranging from yellow-green to red (MARTINS et al., 2007; FARAH et al., 2013).

\section{Mitochondrial membrane potential}

Mitochondria are localized in the middle area of sperm flagellum in a helical configuration (MORTIMER, 1997). Mitochondria are responsible for ATP production via oxidative phosphorylation to support sperm motility (GARNER et al., 1997).
Mitochondria activity is a key indicator of sperm function, and it is detected as the mitochondrial membrane potential, which is measured using fluorescent probes. Rhodamines and carbocianinas are cation fluorescent dyes with affinity for the mitochondrial membrane potential (GILLAN; MAXWELL, 1999). These dyes accumulate in the cells, especially in the mitochondrial matrix region.

Rhodamine 123 (R123) only stains mitochondria of living cells (BENEL et al., 1986), which results in fluorescent images. R123 stains indicate mitochondrial membrane potential, but it has the disadvantage of not identifying the level of the membrane potential (REEN et al., 1991).

MitoTracker is another option to assess mitochondrial potential. This fluorochrome is available in three different emission colors: green, orange or red (SILVA; GADELLA, 2006; FARAH et al., 2013). The color emission is a feature that should be considered when multiple fluorescent probes are used.

JC-1 (iodide, 5,5 ', 6,6' - tetrachloro - 1,1 ', $3,3^{\prime}$ - tetraetilbenzimidazolil-carbocyanine) is a cationic fluorochrome that differentiates the level of membrane potential. JC-1 emits two patterns of color: orange for spermatozoa that have high mitochondrial potential, or green, in sperm cells with low mitochondria potential (REEN et al., 1991).

However, the use of cationic dyes, such as MitoTracker, does not identify different levels of mitochondrial potential groups, which can be a disadvantage compared to the use of JC-1. CottetRousselle et al. (2011) noted that it is necessary to use the correct probe because a false high emission color may be observed with these fluorochromes based on the concentrations used. Mitochondria are important organelles in cellular homeostasis and flagellar beating and motility. Mitochondria functionality is correlated with motility and viability (YOON etal., 2015). However, the importance of this assessment should be questioned because a decrease 
in membrane potential is not necessarily associated with a defect in sperm, and a high potential is not required for hyperactivation, binding to the zona pellucida or acrosome reaction (PETRUNKINA; HARRISON, 2013). Therefore, the assessment mitochondria potential is unnecessary if the highest corrrelation of membrane potential occurs with motility when the sample is analyzed using CASA.

\section{Association of fluorescent probes}

The search for objective and practical results led to the development of several probe associations. The most commonly used combinations are PI and Hoechst 33342, PI and SYBR-14, and PI and C-FDA for PM integrity assessment (SEGOVIA et al., 2000; HALLAP et al., 2006; CELEGHINI et al., 2007; HOSSAIN et al., 2011). Lectin PNA and PSA are commonly associated with PI for evaluations of acrosome integrity (CELEGHINI et al., 2007; MACHADO et al., 2009; CARVALHO et al., 2010; CARRETERO et al., 2015). The combination between Hoechst 33258 and CTC has also been extensively used for capacitation (YOON et al., 2015).

More recent studies using flow cytometry associated dyes such as YoPro-1 (SAPANIDOU et al., 2015), which assesses PM stability with the Merocyanine 540, which evaluates PM permeability. The combination of Merocyanine 540 with YoPro-1 and Hoechst 33342 was also used to assesses the stability, permeability and integrity of PM as described by Hallap et al. (2006). Similarly, Peña (2015) reported that the combination of YoPro-1 with MitoTracker Red for evaluations of PM stability and mitochondrial potential. The combination of Annexin $\mathrm{V}$ with PI was used to evaluate the number of apoptotic cells in a given sample, as described by Peña et al. (2003).

Thus, we can see that association of probes can be used simultaneously to evaluate in the same population different cellular compartments, in a practical and fast way.

\section{Final Considerations}

Equipment and procedures that facilitate the analysis of sperm cells were developed in the last decades. These improvements provide more accurate assessments of cell integrity by reducing subjectivity and the lack of uniformity across evaluation methods. These improvements were achieved by the use of complementary techniques to evaluate other attributes of sperm cells that are not measured in routine tests. This information is essential to clarify and identify the causes of low fertility when apparently normal semen samples produce low rates of pregnancy.

The use of flow cytometry to replace epifluorescencemicroscopyhas led to greaterobjectivity and standardization of assessments performed with fluorescent probes. Flow cytometry allows the use of various fluorochromes simultaneously and the analysis of a large number of cells. The increasing number of commercially available fluorophores and the easy use of these substances increased the potential use of the technique.

Flow cytometry is performed using one or two probes (colors) that are configured for one or two lasers in the majority of the cases. Current equipment is more sophisticated and allows the use multiple excitation sources to detect a large number of parameters. Therefore, the number of tests that can be potentially used for sperm physiology evaluations has increased significantly. The current trend is the development of multicolor systems to enable the rapid evaluation of several attributes in individual spermatozoa.

This type of test can simultaneously assess several regions of the sperm and sperm functions in a large number of cells. It also allows obtaining data from different populations within the same sample. The evaluation of subpopulations with different physiological states within the same sample will allow a more objective analysis with a high degree of repeatability and better correlations with field fertility. 


\section{Acknowledgments}

We thank Embrapa, FAP-DF, CNPq and the Universidade de Brasília.

\section{References}

AGARWAL, A.; SAID, T. M. Role of sperm chromatin abnormalities and DNA damage in male infertility. Human Reproduction Update, Oxford, v. 9, n. 4, p. 331345, 2003.

AMANN, R. P.; HAMMERSTEDT, H. In vitro evaluation of sperm quality: an opinion. Journal of Andrology, Philadelphia, v. 14, n. 6, p. 397-406, 1993.

BACCETTI, B.; GAMBERA, L.; MORETTI, E.; PIOMBONI, P. A quick molecular method for the simultaneous detection in spermatozoa of nuclear, acrosomal and axonemal structure by fluorescent microscopy. Journal of Submicroscopic Cytology and Pathology, Bolonha, v. 31, n. 4, p. 563-569, 1999.

BAKER, S. S.; THOMAS, M.; THALER, C. D. Sperm membrane dynamics assessed by changes in lectin fluorescence before and after capacitation. Journal of Andrology, Philadelphia, v. 25, n. 5, p. 744-751, 2004.

BANASZEWSKA, D.; ANDRASZEK, K.; CZUBASZEK, M.; BIESIADA-DRZAZGA, B. The effect of selected staining techniques on bull sperm morphometry. Animal Reproduction Science, Manchester, v. 159, p. 17-24, 2015.

BARTH, A. D.; OKO, R. J. Abnormal morphology of bovine spermatozoa. Ames: Iowa State University, 1989. $285 \mathrm{p}$.

BENEL, L.; RONOT, X.; KORRTPROBST, M.; ADOLPHE, M.; MOUNOLOU, J. C. Mitochondria1 uptake of rhodamine 123 by rabbit articular chondrocytes. Cytometry A, Madison, v. 7, n. 3, p. 281-285, 1986.

BERGQVIST, A. S.; BALLESTER, J.; JOHANNISSON, A.; LUNDEHEIM, N.; RODRIGUEZ-MARTINEZ, H. Heparin and dermatan sulphate induced capacitation of frozen-thawed bull spermatozoa measured by merocyanine-540. Zygote, Cambridge, v. 15, n. 3, p. 225232, 2007.

BILGILI, S. F.; RENDEN, J. A. Fluorometric determination of avian sperm viability and concentration. Poultry Science, Champaign, v. 63, n. 11, p. 2275-2277, 1984.

BRITO, L. F. C.; BARTH, A. D.; BILODEAUGOESEELS, S.; PANICH, P. L.; KASTELIC, J. P. Comparison of methods to evaluate the plasmalemma of bovine sperm and their relationship with in vitro fertilization rate. Theriogenology, Oxford, v. 60, n. 8, p. 1539-1551, 2003.

CABALLERO, I.; VAZQUEZ, J. M.; MAYOR, G. M.; ALMINANA, C.; CALVETE, J. J.; SANZ, L.; ROCA, J.; MARTINEZ, E. A. PSP-I/PSP-II spermadhesin exert a decapacitation effect on highly extended boar spermatozoa. International Journal of Andrology, Madison, v. 32, n. 5, p. 505-513, 2009.

CARRETERO, M. I.; FUMUSO, F. G.; NEILD, D. M.; GIULIANO, S. M.; CETICA, P.; MIRAGAYA, M. H. Evaluation of the acrosomal status in Lama glama sperm incubated with acrosome reaction inducers. Animal Reproduction Science, Manchester, v. 160, p. 1-11, 2015.

CARVALHO, J. O.; SARTORI, R.; MACHADO, G. M.; MOURAO, G. B.; DODE, M. A. Quality assessment of bovine cryopreserved sperm after sexing by flow cytometry and their use in in vitro embryo production. Theriogenology, Oxford, v. 74, n. 9, p. 1521-1530, 2010.

CELEGHINI, E. C.; ARRUDA, R. P.; ANDRADE, A. F.; NASCIMENTO, J.; RAPHAEL, C. F. Practical techniques for bovine sperm simultaneous fluorimetric assessment of plasma, acrosomal and mitochondrial membranes. Reproduction Domestic Animals, Berlin, v. 42, n. 5, p. 479-488, 2007.

CHAN, P. J.; CORSELLI, J. U.; JACONSON, J. D.; PATTON, W. C.; KING, A. Correlation between intact sperm acrosome assessed using the spermatic stain and sperm fertilizing capacity. Journal of Andrology, Philadelphia, v. 36, n. 1, p. 25-27, 1996.

COLLIN, S.; SIRARD, M.-A.; DUFOUR, M.; BAILEY, J. L. Sperm calcium levels and chlortetracycline fluorescence patterns are related to the in vivo fertility of cryopreserved bovine semen. Journal of Andrology, Philadelphia, v. 21, n. 6, p. 938-943, 2000.

COMBS, C. A. Fluorescence microscopy: a concise guide to current imaging methods. Current Protocols in Neuroscience, Maryland, v. 50, n. 2-1, p. 1-14, 2010.

CORMIER, N.; SIRARD, M.-A.; BAILEY, J. L. Premature capacitation of bovine spermatozoa is initiated by cryopreservation. Journal of Andrology, Philadelphia, v. 18, n. 4, p. 461-468, 1997.

COTTET-ROUSSELle, C.; RONOT, X.; LEVERVE, $\mathrm{X}$.; MAYOL, J. F. Cytometric assessment of mitochondria using fluorescent probes. Cytometry A, Madison, v. 79, n. 6, p. 405-425, 2011.

CROSS, N. L.; MEIZEL, S. Methods for evaluating the acrosomal status of mammalian sperm. Biology of Reproduction, Madison, v. 41, n. 4, p. 635-641, 1989. 
DE-PAUW, I. M. C.; SOOM, A. V.; LAEVENS, H.; VERBERCKMOES, S.; KRUIF, A. D. Sperm binding to epithelial oviduct explants in bulls with different nonreturn rates investigated with a new in vitro model. Biology of Reproduction, Madison, v. 67, n. 4, p. 10731079, 2002.

ELLINGTON, J. E.; EVENSON, D. P,; FLEMING,J. E.; BRISBOIS, R. S.; HISS, G. A.; BRODER, S. J.; WRIGHT, R. W. Coculture of human sperm with bovine oviduct epithelial cells decreases sperm chromatin structural changes seen during culture in media alone. Fertility and Sterility, New York, v. 69, n. 4, p. 643-649, 1998.

FARAH, O. I.; CUILING, L.; JIAOJIAO, W.; HUIPING, $Z$. Use of fluorescent dyes for readily recognizing sperm damage. Journal Reproduction Infertility, Cambridge, v. 14, n. 3, p. 120-125, 2013.

FERNANDEZ-SANTOS, M. R.; MARTINEZ-PASTOR, F.; GARCIA-MACIAS, V.; ESTESO, M. C.; SOLER, A. J.; DE PAZ, P.; ANEL, L.; GARDE, J. J. Extender osmolality and sugar supplementation exert a complex effect on the cryopreservation of Iberian red deer (Cervus elaphus hispanicus) epididymal spermatozoa. Theriogenology, Oxford, v. 67, n. 4, p. 738-753, 2007.

FLESCH, F. M.; GADELLA, B. M. Dynamics of the mammalian sperm plasma membrane in the process of fertilization. Biochimica et Biophysica Acta, Amsterdam, v. 1469, p. 197-235, 2000.

FRASER, L. R.; ABEYDEERA, L. R.; NIWA, K. $\mathrm{Ca} 2+-$ Regulating mechanisms that modulate bull sperm capacitation and acrosomal exocytosis as determined by chlortetracycline analysis. Molecular Reproduction and Development, Malden, v. 40, n. 40, p. 233-241, 1995.

GADELLA, B. M.; HARRISON, R. A. P. The capacitating agent bicarbonate induces protein kinase A-dependent changes in phospholipid transbilayer behavior in the sperm plasma membrane. Development, Cambridge, v. 127, p. 2407-2420, 2000.

GARNER, D. L.; PINKEL, D.; JOHNSON, L. A.; PACE, M. M. Assessment of spermatozoal function using dual fluorescent staining and flow cytometric analyses. Biology of Reproduction, Madison, v. 34, n. 1, p. 127138, 1986 .

GARNER, D. L.; THOMAS, C. A.; JOERG, H. W.; DELARNETTE, M.; MARSHALL, C. E. Fluorometric assessments of mitochondrial function and viability in cryopreserved bovine spermatozoa. Biology of Reproduction, Madison, v. 57, n. 6, p. 1401-1406, 1997.

GILBERT, S. F. Biologia do desenvolvimento. 5. ed. São Paulo: FUNPEC, 2003. 918 p.
GILLAN, L.; KROETSCH, T.; MAXWELL, W. M.; EVANS, G. Assessment of in vitro sperm characteristics in relation to fertility in dairy bulls. Animal Reproduction Science, Manchester, v. 103, n. 3-4, p. 201-214, 2008.

GILLAN, L.; MAXWELL, W. M. The functional integrity and fate of cryopreserved ram spermatozoa in the female tract. Journal Reproduction Fertility, Oxford, v. 54, p. 271-283, 1999.

GWATHMEY, T. M.; IGNOTZ, G. G.; MUELLER, J. L.; MANJUNATH, P.; SUAREZ, S. S. Bovine seminal plasma proteins PDC-109, BSP-A3, and BSP-30-kDa share functional roles in storing sperm in the oviduct. Biology Reproduction, Madison. v. 75, n. 4, p. 501-507, 2006.

HALANGK, W.; FRANK, K.; BOHNENSACK, R. Determination of the quantity of intact spermatozoa in bull ejaculates. Archiv Experimentelle Veterinarmedizin, Berlin, v. 38, n. 1, p. 105-114, 1984.

HALLAP, T.; NAGY, S.; JAAKMA, U.; JOHANNISSON, A.; RODRIGUEZ-MARTINEZ, H. Usefulness of a triple fluorochrome combination Merocyanine 540/Yo-Pro 1/ Hoechst 33342 in assessing membrane stability of viable frozen-thawed spermatozoa from estonian Holstein AI bulls. Theriogenology, Oxford, v. 65, n. 6, p. 1122-1136, 2006.

HANCOCK, J. L. A. Staining technique for the study of temperature-shock in semen. Nature, London, v. 167, n. 4243, p. 323-324, 1951.

HARRISON, R. A. P.; JACQUES, M. L.; MINGUEZ, M. L. P.; MILLER, N. G. A. Behaviour of ejaculated spermatozoa from bull, boar and ram during thinlayer countercurrent partition in aqueous two-phase systems. Journal of Cell Science, Madison, v. 102, p. 123-132, 1992.

HELLMAN, B.; VAGHEF, H.; BOSTROM, B. The concepts of tail moment and tail inertia in the single electrophoresis assay. Mutation Research, Amsterdam, v. 336, n. 2, p. 123-131, 1994.

HOSSAIN, M. S.; JOHANNISSON, A.; WALLGREN, M.; NAGY, S.; SIQUEIRA, A. P.; RODRIGUEZMARTINEZ, H. Flow cytometry for the assessment of animal sperm integrity and functionality: state of the art. Asian Journal of Andrology, Shanghai, v. 13, n. 3, p. 406419, 2011.

KARABINUS, D. S.; VOGLER, C. J.; SAACKE, R. G.; EVENSON, D. P. Chromatin structural changes in sperm after scrotal insulation of Holstein bulls. Journal of Andrology, Philadelphia, v. 18, n. 5, p. 549-555, 1997. 
KATO, Y.; NAGAO, Y. Changes in sperm motility and capacitation induce chromosomal aberration of the bovine embryo following intracytoplasmic sperm injection. PLoS One, Nevada, v. 10, n. 6, p. 1-17, 2015.

KHALIFA, T.A.; REKKAS, C.A.; LYMBEROPOULOS, A. G.; SIOGA,A.; DIMITRIADIS, I.; PAPANIKOLAOU, T. Factors affecting chromatin stability of bovine spermatozoa. Animal Reproduction Science, Manchester, v. 104, n. 2-4, p. 143-163, 2008.

KNOBIL, E.; NEILL, J. D. Knobil and neill's physiology of reproduction. $3^{\text {th }}$ ed. Amsterdam: Elsevier, 2006. 3191 p.

KOSOWER, N. S.; KATAYOSE, H.; YANAGIMACHI, $\mathrm{R}$. Thiol-disulfide status and acridine orange fluorescence of mammalian sperm nuclei. Journal of Andrology, Philadelphia, v. 13, n. 4, p. 342-348, 1992.

KUMAR, D.; KUMAR, P.; SINGH, P.; YADAV, S. P.; YADAV, P. S. Assessment of sperm damages during different stages of cryopreservation in water buffalo by fluorescent probes. Cytotechnology, Switzerland, v. 6, p. $1-8,2014$.

LICHTMAN, J. W.; CONCHELLO, J. A. Fluorescence microscopy. Nature, London, v. 2, n. 12, p. 910-919, 2005.

MACHADO, G. M.; CARVALHO, J. O.; SIQUEIRA FILHO, E.; CAIXETA, E. S.; FRANCO, M. M.; RUMPF, R.; DODE, M. A. Effect of Percoll volume, duration and force of centrifugation, on in vitro production and sex ratio of bovine embryos. Theriogenology, Oxford, v. 71, n. 71, p. 1289-1297, 2009.

MARTINS, C. F.; DODE, M. N.; BÁO, S. N.; RUMPF, $\mathrm{R}$. The use of the acridine orange test and the TUNEL assay to assess the integrity of freeze-dried bovine spermatozoa DNA. Genetics and Molecular Researcher, Ribeirão Preto, v. 6, n. 1, p. 94-104, 2007.

MOCÉ, E.; GRAHAM, J. K. In vitro evaluation of sperm quality. Animal Reproduction Science, Manchester, v. 105, n. 1-2, p. 104-118, 2008.

MOCÉ, E.; GRAHAM, J. K.; SCHENK, J. L. Effect of sex-sorting on the ability of fresh and cryopreserved bull sperm to undergo an acrosome reaction. Theriogenology, Oxford, v. 66, n. 4, p. 929-936, 2006.

MORTIMER, S. T. A critical review of the physiological importance and analysis of sperm movement in mammals. Human Reproduction, Oxford, v. 3, n. 5, p. 403-439, 1997.

PAL, S. K.; MANDAL, D.; BHATTACHARYYA, K. Photophysical processes of ethidium bromide in micelles and reverse micelles. Journal Physycal Chemistry,
Washington, v. 102, n. 58, p. 11017-11023, 1998.

PEÑA, F. J. Multiparametric flow cytometry: a relevant tool for sperm function evaluation. Animal Reproduction Science, Manchester, v. 12, n. 3, p. 351-355, 2015.

PEÑA, F. J.; JOHANNISSONB, A.; WALLGRENA, M.; RODRIGUEZ-MARTINEZ, H. Assessment of fresh and frozen-thawed boar semen using an Annexin- $\mathrm{V}$ assay: a new method of evaluating sperm membrane integrity. Theriogenology, Oxford, v. 60, n. 4, p. 677-689, 2003.

PEREZ, L. J.; VALCÁRCEL, A.; HERAS, M. A. D. L.; MOSES, D.; BALDASSARRE, H. Evidence that frozen/thawed ram spermatozoa show accelerated capacitation in vitro as assessed by chlortetracycline assay. Theriogenology, Oxford, v. 46, n. 1, p. 131-140, 1996.

PETRUNKINA, A. M.; HARRISON, R. A. Fluorescence technologies for evaluating male gamete (dys)function. Reproduction Domestic Animals, Berlin, v. 48, n. 1, p. 11-24, 2013.

PLOEM, J. S.; WALTER, F. Multi-wavelength epiillumination in fluorescence microscopy. Leica Microsystems CDR. [S.1.: s.n.], 2001. Available at: $<$ http://www.leica-microsystems.com/science-lab/ multi-wavelength-epi-illumination-in-fluorescencemicroscopy/>. Accessed at: 24 mar. 2015.

REEN, M.; SMITH, T. W.; CHENS, L. B. J-aggregate formation of a carbocyanine as a quantitative fluorescent indicator of membrane potential. Biochemistry, Boston, v. 30, n. 18, p. 4480-4486, 1991.

RODRIGUEZ-MARTINEZ, H. Can we increase the estimative value of semen assessment? Reproduction Domestic Animals, Berlin, v. 41, n. 2, p. 2-10, 2006.

SALING, P. M.; STOREY, B. T. Mouse gamete interactions during fertilization in vitro: chlortetracycline as a fluorescent probe for the mouse sperm acrosome reaction. Journal Cell Biology, New York, v. 83, n. 3, p. 544-555, 1979.

SAPANIDOU, V.; TAITZOGLOU, I.; TSAKMAKIDIS, I.; KOURTZELIS, I.; FLETOURIS, D.; THEODORIDIS, A.; ZERVOS, I.; TSANTARLIOTOU, M. Antioxidant effect of crocin on bovine sperm quality and in vitro fertilization. Theriogenology, Oxford, v. 84, n. 8, p. 1273 1282, 2015.

SEGOVIA, M.; JENKINS, J. A.; PANIAGUACHAVEZ, C.; TIERSCH, T. R. Flow cytometric evaluation of antibiotic effects on viability and mitochondrial function of refrigerated spermatozoa of nile tilapia. Theriogenology, Oxford, v. 53, n. 7, p. 14891499, 2000. 
SILVA, P. F.; GADELLA, B. M. Detection of damage in mammalian sperm cells. Theriogenology, Oxford, v. 65, n. 5, p. 958-978, 2006.

SOSA, C. M.; PAVAROTTI, M. A.; ZANETTI, M. N.; ZOPPINO, F. C.; DE BLAS, G. A.; MAYORGA, L. S. Kinetics of human sperm acrosomal exocytosis. Molecular Human Reproduction, Oxford, v. 21, n. 3, p. 244-254, 2015.

STANDERHOLEN, F. B.; MYROMSLIEN, F. D.; KOMMISRUD, E.; ROPSTAD, E.; WATERHOUSE, K. E. Comparison of electronic volume and forward scatter principles of cell selection using flow cytometry for the evaluation of acrosome and plasma membrane integrity of bull spermatozoa. Cytometry, New York, v. 85-A, n. 8, p. 719-728, 2014.

THOMAS, C. A.; GARNER, D. L.; DEJARNETTE, M.; MARSHALL, C. E. Fluorometric assessments of acrosomal integrity and viability in cryopreserved bovine spermatozoa. Biology of Reproduction, Madison, v. 56, n. 4, p. 991-998, 1997.

THUNDATHIL, J.; PALASZ, A. T.; MAPLETOFT, R. J.; BARTH, A. D. An investigation of the fertilizing characteristics of pyriform-shaped bovine spermatozoa. Animal Reproduction Science, Manchester, v. 57, n. 1-2, p. 35-50, 1999.

VALCÁRCEL, A.; HERAS, M. A. D. L.; PKREZ, L.; MOSES, D. F.; BALDASSARRE, H. Assessment of the acrosomal status of membrane-intact ram spermatozoa after freezing and thawing, by simultaneous lectin/ Hoechst 33258 staining. Animal Reproduction Science, Manchester, v. 45, n. 4, p. 299-309, 1997.
WILSON, H. R.; WARNICK, A. C.; GUTIERREZ, J. H. Differentiation of live from dead spermatozoa in cock semen. Poultry Science, Champaign, v. 48, n. 2, p. 714 717, 1969.

YÁNIZ, J. L.; PALACÍN, I.; VICENTE-FIEL, S.; GOSALVEZ, J.; LÓPEZ-FERNÁNDEZ, C.; SANTOLARIA, P. Evaluation of a commercial kit based on acridine orange/propidium iodide to assess the plasma membrane integrity of ram sperm. Spanish Journal of Agricultural Research, Madrid, v. 11, n. 2, p. 362-365, 2013.

YOON, S. J.; KWON, W. S.; RAHMAN, M. S.; LEE, J. S.; PANG, M. G. A novel approach to identifying physical markers of cryo-damage in bull spermatozoa. PLoS One, Nevada, v. 10, p. 1-12, 2015.

YOUNG, K. E.; ROBBINS, W.A.; XUN, L.; ELASHOFF, D.; ROTHMANN, S. A.; PERREAULT, S. D. Evaluation of chromosome breakage and DNA integrity in sperm: an investigation of remote semen collection conditions. Journal of Andrology, Philadelphia, v. 24, n. 6, p. 853861, 2003.

ZHANG, J.; BOYLE, M. S.; SMITH, C. A.; MOORE, H. D. M. Acrosome reaction of stallion spermatozoa evaluated with monoclonal antibody and zona-free hamster eggs. Molecular Reproduction and Development, Malden, v. 27, n. 2, p. 152-158, 1990. 